\title{
Turizm Sektörünün Türkiye Ekonomisine Etkisi: ARDL Sınır Testi Yaklaşımı
}

\author{
Ecem TURGUT * (iD \\ Okyay UÇAN** (D) \\ Nizamettin BAŞARAN*** (D)
}

\section{ÖZ}

Turizm; insanların gezme, dinlenme, eğlenme, öğrenme gibi çeşitli amaçlar doğrultusunda başka bölgelere seyahat etmeleri sonucunda gerçekleșmektedir. İnsanlar tarafindan gerçekleștirilen bu seyahat faaliyetleri özellikle gelișmiș ve gelișmekte olan ülke ekonomilerine çeşitli yönlerden fayda sağlayarak büyüme oranları üzerinde etkili olmaktadır. Bu sebepten ülkeler turizm sektörüne giderek daha fazla önem vermekte ve bu sektörü geliştirmek için çeşitli politikalar ve stratejiler uygulamaktadırlar. Turizm ve büyüme ilişkisi literatürde turizme dayalı büyüme ve büyümeye dayalı turizm şeklinde ayrı ayrı incelenmektedir. Dolayısıyla turizm ve büyüme karșılıklı olarak birbirlerini etkileyerek ülkelerin kalkınmasında önemli rol oynamaktadır. Bu çalışmada 1998:Q12019:Q4 dönemi verilerinden yararlanılarak turizm ve büyüme ilişkisinin analiz edilmesi amaçlanmıştır. Çalışmada reel gayri safi yurtiçi hasıla büyümeyi gösterirken, turizm gelirleri ve yabancı ziyaretçi sayısı da turizmi temsil etmektedir. Analiz kapsamında öncelikli olarak sınır testi yapılmıș ve değișkenler arasında uzun dönemli bir ilișki olduğu sonucuna ulașılmıștır. Akabinde hata düzeltme modeli incelenerek kısa dönemde meydana gelen dengesizliklerin sonraki dönemde düzelebileceği belirlenmiştir. Değişkenler arasındaki nedensellik ilişkisinin test edilmesi için yapılan Granger nedensellik testi sonucunda da yabancı ziyaretçi sayısının ve turizm gelirlerinin büyümenin Granger nedeni olduğu anlaşılmıştır. Sonuç olarak turizm ve ekonomik büyüme arasında ilişki bulunurken, Granger nedensellik analizinin ampirik sonuçları Türkiye'de turizm’e dayalı büyümeyi doğrulamıștr.

Anahtar Kelimeler: Turizm, Ekonomik Büyüme, Zaman Serisi Analizi, ARDL Sınır Testi

\section{Effect of Tourism Sector on Turkish Economy: ARDL Bounds Testing Approach}

\begin{abstract}
Tourism occurs as a result of people traveling to other regions for various purposes such as traveling, resting, entertainment and learning. These travel activities carried out by people have an impact on growth rates by benefiting especially the economies of developed and developing countries from various aspects. For this reason, countries give more importance to the tourism sector and implement various policies and strategies to develop this sector. The relationship between tourism and growth is examined separately growth-led tourism and tourism-led growth. Therefore, tourism and growth play an important role in the development of countries by mutually influencing each other. This study purposes to analyze the relationship between tourism and growth by using the data of 1998:Q1-2019:Q4 period. In the study, real gross domestic product indicates growth while tourism revenues and the number of foreign visitors represent tourism. Within the scope of the analysis, primarily a bounds test is performed and it is concluded that there is a long-term relationship between the variables. Subsequently, the error correction model is examined and it is determined that the imbalances occurring in the short term can be corrected in the next period. As a result of the Granger causality test conducted to test the causality relationship between the variables, it is understood that the number of foreign visitors and tourism revenues are the Granger reasons for growth. As a result, we found the relationship between tourism and economic growth, and empirical results of the Granger causality analysis verify tourism-led growth in Turkey.
\end{abstract}

Keywords: Tourism, Economic Growth, Time Series Analysis, ARDL Bounds Test

\section{Giriş}

İnsanlar, sürekli olarak yaşadıkları yerlerden geçici bir süreliğine ayrılarak gezip-görme, dinlenme, eğlenme, öğrenme gibi çeşitli amaçlarla başka ülkelere ya da bölgelere gitmektedirler. Gelişmiş ve gelişmekte olan ekonomiler açısından önemli etkileri olan bu süreç, turizm olarak tanımlanmaktadır. Turizm; latince "tornus" kelimesinden gelmekte ve insanların bir eksen etrafinda dönme hareketini ifade etmektedir. İngilizce ve Almanca gibi yaygin dünya dillerine ise bu kelime "tour" olarak nüksetmiş ve bu kavram insanların dairesel hareketler içerisinde görülmeye değer yerleri iş ya da eğlence amaciyla gezip gördükten sonra geri dönmelerini ifade etmektedir (Ylldız, 2011, s. 55).

\footnotetext{
* Doktora Öğrencisi, Niğde Ömer Halisdemir Üniversitesi, ecemtrgtt@gmail.com

** Prof. Dr., Niğde Ömer Halisdemir Üniversitesi, okyayu@hotmail.com

*** Dr. Öğr. Üyesi, Niğde Ömer Halisdemir Üniversitesi, nbasaran@ohu.edu.tr

Makalenin Gönderim Tarihi: 06.11.2020 , Makalenin Kabul Tarihi: 05.01.2021
} 
Turizm faaliyetlerini gerçekleştiren bu kişilere ziyaretçi denilmektedir. Devamlı ikamet ettiği ülkeden başka bir ülkeye 12 aydan daha kısa bir süre için, herhangi bir kâr amacı gütmeden, çeşitli nedenlerle ziyaret eden kişileri ifade eden ziyaretçi kavramı, turistleri ve günübirlikçileri bünyesinde bulundurmaktadır. Sonuçta bu kavramlar arasında net tanımsal farklııklar ortaya çıkmaktadır. İki kavram arasındaki en temel fark ise ziyaret edilen ülkede ya da bölgede kalınan süreden kaynaklanmaktadır. Günübirlikçi, ziyaret edilen ülkede veya bölgede 24 saatten az kalan ve geceleme yapmayan ziyaretçilere denilirken; turist, ziyaret ettiği ülkede en az 24 saat kalarak seyahat eden ziyaretçilere verilen isimdir (Koçtepe, 2019, ss. 7-8).

Turizme yönelik yapılan bu açıklamalar bir sürecin turizm olarak nitelendirilmesi için belirli özellikleri bünyesinde bulundurması gerektiğini ortaya koymaktadır. Bu çerçevede turizmin özellikleri aşağıda sıralanmıştır (Serin Karacaer, 2019, s. 25):

- Turizm, tek bir olaydan ziyade olgu ve ilişkilerin bir karışımıdır. Dolayısıyla çeşitli sektörlerin koordineli bir şekilde çalışmalarını gerektirmektedir.

- Sürekli yaşanılan yer dışındaki bir yere belirli bir süreliğine gidilmesi, turizm olgusunun geçicilik Özelliği sergilediğini göstermektedir. Yani turizm geçici ve kısa süreli bir olgudur.

- Turizm faaliyeti sırasında, herhangi bir nedenle seyahate çıkan kişilerin tüketici olma özelliği sergilemesi gerekmektedir. Bir diğer ifadeyle seyahat eden kişilerin doğrudan gelir sağlayıcı bir amaca yönelmemesi gerekmektedir.

- Turizm faaliyetinde bulunan kişilerin turizm işletmelerinden yararlanması gerekmektedir.

Turizme yönelik sıralanan tüm bu özellikler turizmin; çeşitli amaçlar ile insanların seyahat, ulaşım, konaklama, eğlenme gibi istek ve ihtiyaçlarına hizmet eden hem insanlar açısından hem de ülke ekonomileri açısından büyük bir öneme sahip olan bir sektör olduğu anlaşılmaktadır.

Ekonomi ise, insanların sınırsız tüketim isteklerinin sınırlı kaynaklarla en iyi şekilde nasıl yönetileceğini ya da tatmin edileceğini inceleyen sosyal bir bilim dalıdır. Ekonomi biliminde talep, belirli bir dönem içerisinde belirli bir malın farklı fiyat düzeylerinde tüketiciler tarafindan satın alınmak istenen mal miktarı olarak tanımlanmaktadır. Arz ise belirli bir zaman diliminde, ceteris paribus varsayımı altında, belirli fiyat düzeylerinden satılmak istenen mal ve hizmet miktarları olarak ifade edilmektedir. Turizm ekonomisi ise bu doğrultuda insanların turistik ihtiyaçlarını ve isteklerini karşılamaya yönelik yapılan çabalar bütünüdür. Dolayısıyla turizm talebi, satın alma gücüyle desteklenen turistik satın alma isteği; turizm arzı ise belirli bir zaman diliminde satılmak istenen turistik mal ve hizmetler bütünü olarak tanımlanabilmektedir. (Bilgiçli ve Altnkaynak, 2016, ss. 561-562). ). Turizm arz ve talebinin özellikleri ve belirleyicileri Tablo 1'de gösterilmiştir.

Tablo 1. Turizm Arz ve Talebinin Özellikleri ile Belirleyicileri

\begin{tabular}{|c|c|c|}
\hline & Özellikleri & Etkileyen Faktörler \\
\hline 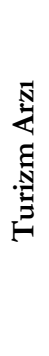 & $\begin{array}{l}\text {-Turizm arzının gerçekleşebilmesi için belli yatırımlar gereklidir. } \\
\text {-Turistik mal ve hizmetlerin üretildiği anda tüketime sunulması gerekmektedir. Çünkü } \\
\text { stoklanması mümkün değildir ve turizmde emek yoğun bir üretim söz konusudur. } \\
\text { - Kısa dönemde inelastik olup turistik ürünler için ek bir arz anında oluşturulamamaktadır. } \\
\text {-Tüketici, turistik bir ürünü satın alabilmek ve tüketmek için turistik arzın bulunduğu yere } \\
\text { gitmek zorundadır. } \\
\text { - Üretilen ürün hizmettir ve yıl boyu süreklilik gerektirmektedir. } \\
\text {-Turizm ürünleri soyut bir özellik sergilemektedir. } \\
\text {-Turizm arzı her faktörden ve sektörden etkilenmektedir. Dolayısıyla herhangi bir } \\
\text { sebepten ortaya çıkacak olumsuz bir sonuç turizmi de olumsuz etkilemektedir. }\end{array}$ & $\begin{array}{l}\text {-Tarihi varlıklar } \\
\text { - Kültürel varlıklar } \\
\text { •Coğrafi çekicilik } \\
\text { - ̇̇klim } \\
\text { - Altyapı ve üstyapı olanakları }\end{array}$ \\
\hline 章 & $\begin{array}{l}\text {-Turizm talebi otonomdur. } \\
\text {-Turizm talebi heteronomdur. } \\
\text { - Kişisel gelirin kullanılmasını gerektirmektedir. } \\
\text {-İkame olanağı yüksektir. Dolayısıyla turizm ürünlerinin tüketilmesinde ekonomik, sosyal, } \\
\text { politik ve mali faktörlerin etkisinin yükselmesine neden olmaktadır. } \\
\text { - Fazlasıyla esnektir. } \\
\text {-Turistik ürünler ile aynı özellikteki ürünler arasında rekabet vardır. } \\
\text { •Mevsimsel özellik taşımakta ve bireylerin isteklerine bağlıdır. } \\
\text { •Her geçen zaman diliminde yeni eğilimler kazanmaktadır. }\end{array}$ & $\begin{array}{l}\text { - Gelir düzeyi } \\
\text {-Seyahat edilecek yerin fiyat düzeyi } \\
\text {-Döviz kurları } \\
\text {-Uzaklık ve Ulaştırma maliyetleri } \\
\text { - Konaklama ve Ulaşım İmkânları } \\
\text { - Reklam ve tanıtım } \\
\text {-Eğitim düzeyi ve sağllk } \\
\text {-Yaş, cinsiyet ve aile yapisı } \\
\text {-Dil güçlükleri } \\
\text { - Kentleşme düzeyi } \\
\text {-Politik ve yasal faktörler }\end{array}$ \\
\hline
\end{tabular}

Kaynak: (Akar, 2020, ss. 8-26). 
Tablo 1'de de görüldüğü üzere turizm birçok unsur ile etkileşimde olan bir sektör olup özellikle de ekonomi ile doğrudan bir bağlantı halindedir. Ekonomik şartlar, turizm açısından öneme sahip olan tesis ve hizmet arzının yanı sıra turizm talebinde de önemli derecede etkin bir rol oynamaktadır. Seyahat maliyetleri ve kişilerin mali durumlanı bireylerin turizm kararlarını etkilemektedir. Dolayısıyla sağlıklı bir ekonomi turizm sektöründe ihtiyaç duyulacak yurt içi ve yurt dışı ulaşımında, yatırım için mevcut kaynakların belirlenmesinde yardımcı olmaktadır. Ayrıca kendine özgü iç ekonomik dinamikleri olan turizm sektörü üzerinde, ulusal ve uluslararası ekonomilerin yapıları önemli etkiler yaratmaktadır. Değişimin niteliğine bağlı olarak ürün ve fiyatlar konusunda destinasyonların çekiciliğinin daha fazla ya da daha az olması kaynak pazardaki talep üzerinde olumsuz bir etki yaratacak ya da canlanmasını sağlayacakttr. Bu durum ülkelerin kalkınmaları ve ekonomik büyümelerini artırmaları için turizm sektörüne ihtiyaç duydukları gibi turizm sektörünün gelişmesi için de gelişmiş bir ekonomik özelliklere ihtiyaç duyulacağını göstermektedir. Kısacası ekonomi ve turizm birbirlerini karşılıklı olarak etkileyen iki kavram olarak kendini göstermektedir. Dolayısıyla turizm sektörü büyüme oranları artırmak isteyen ülkeler için lokomotif sektör özelliği göstermiştir. Turizm sektörü özellikle 20. yüzyllın ikinci yarısından itibaren, dünya ekonomisinde en hızlı gelişen ve ilerleyen sektörlerden biri haline gelmiştir. (Zengin, 2010, s. 106).

Dünyanın en hızlı gelişen sektörlerinden biri olan turizm sektörü, başta gelişmekte olan ülkeler olmak üzere tüm dünya ülkelerinin ekonomileri için potansiyel bir gelir kaynağı oluşturmaktadır. Turizm sektörü, uluslararası ticarette büyük bir paya ve öneme sahip olmakla birlikte görünmez bir ihracat kalemi olarak ekonomik büyümeye önemli katkılar sağlamaktadır. Diğer yandan turizm potansiyeline sahip ve destinasyon oranı yüksek ülkelerin çoğunda istihdama, iç ve dış borç yükünü hafifleterek ödemeler dengesinin iyileşmesine ve sonuç olarak ülkelerin refah düzeyinin yükselmesine önemli ölçüde katk1 sağlamaktadır (Dücan, Şit ve Şentürk, 2016, s. 2).

Turizm sektöründen pay alma çabası içinde olan ülkeler, gelişmişlik düzeylerine göre farklılık göstermektedir. Ancak her ülke turizm sektöründen elde edebileceği yararlanı kendi imkân ve olanakları ile maksimize etmeyi amaçlamaktadır. Bu kapsamda dünyada turizm hareketleri hızla gelişme göstermekte ve Türkiye'de hem makro hem de mikro bazda turizm sektöründe çok hızlı bir gelişme göstermiştir. Bu surette turizm, Türkiye'nin en büyük ikinci sektörü haline gelmiş ve ülkenin gelişmişlik düzeyine önemli katkılar sağlamıştır. Özellikle dünyada turizm sektöründe izlenen hızlı büyüme eğilimi, Türkiye'de 1980’li yıllardan itibaren ülkenin kalkınmasında rol oynayan öncül sektörlerden biri haline gelmiştir. Literatür incelendiği zaman ise 1983 yllı Türk turizmi açısından canlanma döneminin başlangıcı kabul edilmiştir. $\mathrm{O}$ zamanlardan bugüne kadar Türkiye'de önemli bir yere sahip olan bu sektör, hem turist sayıs hem de turizm gelirleri açısından önemli sayılabilecek artışlar gerçekleştirmiştir (Zortuk ve Bayrak, 2013, s. 41).

Turizm sektörünün ülke ekonomileri açısında bu kadar büyük bir öneme sahip olması turizmin mikro ve makro açıdan ayrı ayrı ele alınmasına olanak sağlamaktadır. Mikroekonomi açısından turizm ele alındığında, turizmde tüketim faaliyetinde bulunan bireylerin hangi ekonomik güdülerle hareket ettiğinin anlaşılması mümkün kılınmaktadır. Ayrıca üretim ve maliyet teorisinin turizm sektörüne uyarlanması sonucunda, turizmde hem kısa hem de uzun dönemli üretim ilişkileri analiz edilebilmektedir. Arz ve talep teorileri de fiyatın belirlenmesi açısından firma ve bireylere bilgiler sunmaktadır. Diğer yandan mikroekonomik anlamda yapılabilecek piyasa analizleri, turizm işletmelerinin pazar payı elde etmek, sahip olunan payı genişletmek ve korumak konusunda geliştirilecek stratejilerin altyapısını oluşturmaya olanak sağlamaktadır. Makroekonomi açısından ise; ulusal gelir hesaplamaları, toplam arz ve toplam talep, para arzı ve talebi, yatırım, tasarruf, kamu harcamaları, enflasyon ve işsizlik gibi birçok konunun turizm sektörüyle bağlantısı bulunmaktadır. Örneğin; turizm harcamaları ve turizm amaçlı yapılan her türlü yatırımlar çarpan (çoğaltan) etkisiyle ekonomiye canlılık kazandırmaktadır (Zengin, 2010, ss. 106-107).

$\mathrm{Bu}$ açıklamalar karşısında turizmin ekonomi üzerinde yarattığı bu tarz etkiler aşağıda maddeler halinde ayrı ayrı açıklanarak konuya net bir bakış açısı oluşturulmuştur:

i) İstihdam Yaratma Etkisi: Turizmin gelişmesine paralel bir şekilde turistik tesis yatırımlarının artması işgücü talebini artırmaktadır. Ayrıca turizmin mevsimsellik özelliğine bağlı olarak talepte bir artı̧̧ yaşandığı dönemlerde turistik işletmeler de işgücüne olan emek talebini artırmaktadır. Bu bağlamda turizm sektöründe ortaya çıkarılan işgücü talebi türetilmiş taleptir. Ayrıca turizm sektörü tek başına düşünülmeyip diğer sektörlerle olan ilişkisinin de göz önünde bulundurulması gerekmektedir. Bu nedenle turizm'in 
istenildiği etkinliği sağlayabilmesi için birçok sektör ile koordineli çalışması gerekmekte ve bu durum diğer sektörlerde istihdam edilecek işgücüne yönelik talebi olumlu yönde desteklemektedir (Çeken ve Ateşoğlu, 2008, s. 145).

Örneğin; turizmin gelişmesine paralel olarak inşa edilen üstyapı tesisleri, daha fazla istihdam ve daha fazla inşaat malzemesi kullanımı anlamına gelmektedir. Bu durum yatırım harcamalarında bir artış ortaya çıkarmakta ve ilk andan itibaren ekonomiye önemli oranda yayılarak yoğun bir gelir akımına neden olmaktadır. Diğer yandan turizm sektöründe doğrudan ve dolaylı istihdam imkânı sağlayan kaynak ise turistler tarafından gerçekleştirilen tüketim harcamalarıdır. Turistik tüketim harcamalarının ilk aşamasında elde edilen gelir direk istihdam etkisi yaratırken, elde edilen gelirlerin tekrar harcanması ikinci derecede istihdam etkisini ortaya koymaktadır (Yıldız, 2011, s. 61).

ii) Gelir Dağılımını Düzenleme ve Bölgeler Arası Dengeli Kalkınmayı Sağlama Etkisi: Turizm, ekonomik dengesizliklerin giderilmesinde ve ülkelerin farklı bölgelerindeki gelir dağılımının dengelenmesinde oldukça etkili olmaktadır (Kızılgöl ve Erbaykal, 2008, s. 354). Turizm sektörü, özellikle tarım ve sanayi gibi sektörlerde yeterli kaynak ve gelişme olanağına sahip olmayan fakat turistik arz potansiyeline sahip bölgelerde, planlı ve etkin bir politika uygulamanın sonucunda, turistik yönden dengeli bir kalkınma sağlamaktadır. Bu duruma paralel bir şekilde turizmin gelir etkisinin artması, ülke içerisinde çok fazla öne çıkmayan tarım sektörünün üretim kalitesinin artmasına, standardizasyonun sağlanmasına ve kaliteli ürünün gerçek değerini bulmasına neden olmaktadır. Sonuç olarak bölgede tarımsal kesimin gelirinde bir artış yaşanmaktadır. Bu şekilde turizm sektörünün doğrudan gelir yaratma etkisinin ve bölgesel kalkınma etkisinin yanı sıra diğer sektörlere de etki ederek o sektörlerde de gelir dağılımın artmasına ve bölgesel kalkınmanın sağlanmasına neden olmaktadır (Çeken, 2008, ss. 279-301).

iii) Döviz Geliri Yaratma ve Ödemeler Dengesi Etkisi: Turizmin girdisi olan dövizler, döviz arz ve talebi yaratmada fazlasıyla etkili olmaktadır. Bu etkiye paralel olarak turizm gelir ve giderleri, bir dış turizm bilançosu yaratarak ödemeler dengesi üzerinde olumlu bir rol üstlenmektedir (Bozgeyik ve Yoloğlu, 2015, s. 631). Bu bağlamda uluslararası turizm, ödemeler dengesinin cari işlemler hesabı altında bulunan hizmetlerin önemli bir kalemini oluşturmaktadır. Uluslararası turizm hareketleri, turist gönderen ülkenin döviz talebini artırırken, turist kabul eden ülkenin ise döviz arzını artırmaktadır. Ayrıca turizm gelirleri, ödemeler dengesi açık veren ülkeler için önemli bir döviz kaynağı yaratmaktadır. Turizm, ulusal ekonomi açısından ek bir ihracat kaynağı yaratmasının da etkisiyle hem gelişmiş hem de gelişmekte olan ülkelerde önemli bir yer bulmuştur. Turizme dayalı gelişme politikası izleyen ülkelerin ödemeler dengesinde gerçekleşen gelişme ve bu alanda elde edilen başarılar ise ülkelerin turizme giderek daha çok önem vermesine neden olmuştur (Gülbahar, 2008, s. 156).

iv) Milli Gelir Üzerindeki Etkisi: Turistik amaçla yapılan seyahatler, söz konusu ülke içerisinde konaklama, gezme, eğlenme, yeme, içme, ulaşım ve alışveriş gibi gereksinimleri karşılamak için harcamaların yapılmasını gerekli kılmaktadır. Yapılan bu harcalar ise ülkenin doğrudan gelirinin artmasına neden olmaktadır (Akın, Şimsek ve Akın, 2012, s. 70). Kısacası ülkeye gelen turistler tarafindan gerçekleştirilen harcamalar bir gelir ortaya çıkarmakta ve bu da milli gelir üzerinde olumlu bir etkide bulunmaktadır. Bu bağlamda turizm bir ülke ekonomisine olan etkisinin tespit edilebilmesi için öncelikli olarak turizm sektörünün Gayrisafi Milli Hasıla (GSMH) içerisindeki yerine bakılması gerekmektedir. Turizmin milli gelire katkıs1; turistik harcamaların toplam tutarı cari piyasa fiyatları ve sabit fiyatlarla hesaplanmakta ve bu tutarın turizm sektörünce satın alınan mal ve hizmetlerin tutarı arasındaki fark, şeklinde hesaplanmaktadır (Zengin, 2010, s. 121).

v) Küçük Ölçekli İşletmelerin Geliştirilmesi ve Yatırım Etkisi: Turizm sektöründe gerçekleştirilen birçok iş, küçük çaplı işletmeler tarafından gerçekleştirilmektedir. Turizmin yerel işletmelerle kurduğu ilişki ise ekonomide oluşan sızıntıları azaltmakta ve iş sahaları da değerlendirilerek potansiyel gelir üzerinde oldukça etkili olmaktadır. (Kızılgöl ve Erbaykal, 2008, s. 354). Diğer yandan bir bölgede turistik doğal çekiciliklerin bulunması turizm yatırımlarının bu bölgeye çekilmesinde etkili olmakta ve böylelikle bölgenin genel altyapı yatırımları da diğer bölgelere göre daha çabuk gerçekleşmektedir. Turistik alt ve üst yapı yatırımları ise bölgeye doğrudan yerli ve yabancı yatırımları çekmektedir. Bu yönden alt ve üst yapıya yatırım yapmak çok uluslu şirketlerin bilgi ve işletme yöntemlerini aktararak yatırım yaptıkları bölgelere yönelik olumlu katkılar sağlamaktadır (Gülbahar, 2008, s. 156). 
Turizmin ekonomi üzerinde bu şekilde pozitif bir etki yaratması turizm sektörünün öne çıkmasına ve ülkelerin geliştirmek için politikalar uyguladı̆̆1 sektörler arasında önemli bir yer tutmasına neden olmuştur. Gelişmekte olan ülkeler arasında yer alan Türkiye'de de özellikle aktif dış turizm 1980'li yıllardan itibaren önemli bir gelişme göstermiştir. 1985 yllında ekonomide uygulanan programlar ile turizm sektörü teşvik edilen sektörler arasında yer almış ve bu alandaki yatırımların, desteklerin ve teşviklerin artmasıyla da ülke ekonomisine önemli oranda katkı sağlayan kaynaklardan biri haline gelmiş hatta kalkınmada lokomotif görevi üstlenmiştir. Bu suretle de Türkiye turizm sektöründe öne geçmeye yönelik politikalar uygulayarak gelişmişlik düzeyini artırmaya çalışmıştır. Dünya turizminde y1llara göre Türkiye'nin sıralamas1 Tablo 2'de gösterilmiştir.

Tablo 2. Dünya Turizminde Yıllara Göre Türkiye'nin Siralaması

\begin{tabular}{|c|c|c|}
\hline Y1llar & Turist Saysinda & Turizm Gelirinde \\
\hline 2002 & 17. & 12. \\
\hline 2003 & 15. & 9. \\
\hline 2004 & 12. & 8. \\
\hline 2005 & 9. & 8. \\
\hline 2006 & 12. & 9. \\
\hline 2007 & 9. & 10. \\
\hline 2008 & 8. & 9. \\
\hline 2009 & 7. & 9. \\
\hline 2010 & 7. & 9. \\
\hline 2011 & 6. & 10. \\
\hline 2012 & 6. & 12. \\
\hline 2013 & 6. & 12. \\
\hline 2014 & 6. & 12. \\
\hline 2015 & 6. & 12. \\
\hline 2016 & 10. & 17. \\
\hline 2017 & 8. & 15. \\
\hline 2018 & 6. & 15. \\
\hline 2019 & 6. & 13. \\
\hline
\end{tabular}

Kaynak: Kültür ve Turizm Bakanlığı, Turizm İstatistikleri (Ocak-Eylül 2020).

Tablo 2'ye bakıldığ1 zaman Türkiye'nin turizm gelirinde 2002 y1lında 12. sırada yer alırken sonraki birkaç yıl içerisinde daha iyi bir sıralamaya yerleştiği görülmüşürr. Ayrıca 2002-2019 dönemleri arasında, turizm gelirleri açısından, Türkiye dünya sıralamasında 8. sırada yer alarak, baz alınan yıllar içerisinde en iyi sıralamaya 2004 ve 2005 yıllarında ulaştı̆̆1 görülmektedir. Ancak bu ilerlemenin sürekli olmayıp zaman içerisinde diğer ülkelerden daha geride kalmış ve 2019 yllında 13. sırada yer aldığı gözlemlenmiştir. Turist sayısı açısından bakıldığında ise 2002 yılında 17. sırada yer alırken Türkiye ülkeye daha fazla turist çekmeyi başarmış ve 2019 yılında dünya ülkeleri arasında 6.sırada yer almayı başarmıştır. Bu doğrultuda Tablo 2'den elde edilen sonuçlar 2019 yllında Türkiye'nin 2002 yılına göre daha fazla turist çekmeyi başarmasına rağmen turizm geliri elde etme de bir ilerleme kat edemediğini ortaya koymuştur. Bu sonuçlar Türkiye'nin sahip olduğu doğal güzellikler ve kültürel zenginlikler gibi ülkenin sahip olduğu turizm potansiyelini rasyonel bir şekilde kullanıp kullanmadığını tartışılan bir konu haline getirmiş ve turizm'in ülkelerin büyüme oranlarına katkı sağlayıp sağlamadığı sürekli tartışılmıştır. Bu bağlamda çalışmada turizm ile ekonomik büyüme arasındaki ilişkinin analiz edilmesi amaçlanmıştır.

Çalışmada Türkiye'nin büyüme, turizm geliri ve yabancı ziyaretçi sayısı verilerinden yararlanılarak değişkenler arasındaki ilişki analiz edilmiştir. Turizm ve büyüme ilişkisini analiz edebilmek için öncelikli olarak değişkenlere birim kök testi uygulanmış ve çıkan sonuçlar doğrultusunda Gecikmesi Dağıtulmış Otoregresif Model (ARDL) ile eşbütünleşme ilişkisi test edilmiştir. Son olarak Granger nedensellik testi yapılarak değişkenler arasında nedensellik ilişkisinin yönü tespit edilerek turizm ve ekonomik büyüme arasındaki ilişki ortaya koyulmuştur. Çalışmanın sonunda ise ülke ekonomilerine ve literatüre fayda sağlayacağının düşünüldüğü bazı önerilerde bulunularak çalışma sonlandırılmıştır. 


\section{Turizm ve Büyüme İlişkisi Literatür Taraması}

Turizm ve ekonomik büyüme ile ilgili çalışmaların çoğu birbirinden farklı sonuçlar ortaya koymuştur. Çalışmaların bazılanında turizm ve ekonomik büyüme arasında anlamlı bir ilişki olduğu ileri sürülürken bazı çalışmalarda ilişki tespit edilememiştir. Buna karşın literatürde değişkenler arasında tek yönlü bir ilişki olduğu sonucuna ulaşılan çalışmalar da bulunmaktadır. Ele alınan çalışmalardaki bu sonuçlar değişkenler arasında çıkan sonuçlara göre çeşitli politikalar uygulanmasını gerekli kılacağından dolayı önem arz etmektedir. Örneğin yapılan çalışmalarda turizmin ülke ekonomisi üzerinde olumlu ve pozitif bir etkisi çıkması sonucunda, ülke içerisinde turizmi teşvik edecek ve destekleyecek politika kararlarının alınması gelişme açısından önemli sonuçlar doğuracaktır. Diğer yandan turizmin ülkede gelişmişlik düzeyine etki etmediğinin saptandığ1 durumlarda ülke ekonomilerine fayda sağlayacak sektörlerin öne çıkmasına yönelik çalışmalara ağırlık verilmesi gerekmektedir. Bundan dolayı çalışmanın bu bölümünde literatürde turizm ve ekonomik büyüme arasındaki ilişkiyi analiz eden çalışmalara yer verilmiş ve bu suretle konuya ilişkin genel bir bakış açısı elde edilmesine olanak sağlanmıştur. Literatür özeti Tablo 3'de verilmiştir.

Tablo 3. Turizm ve Büyüme İlişkisine Yönelik Literatür Taraması

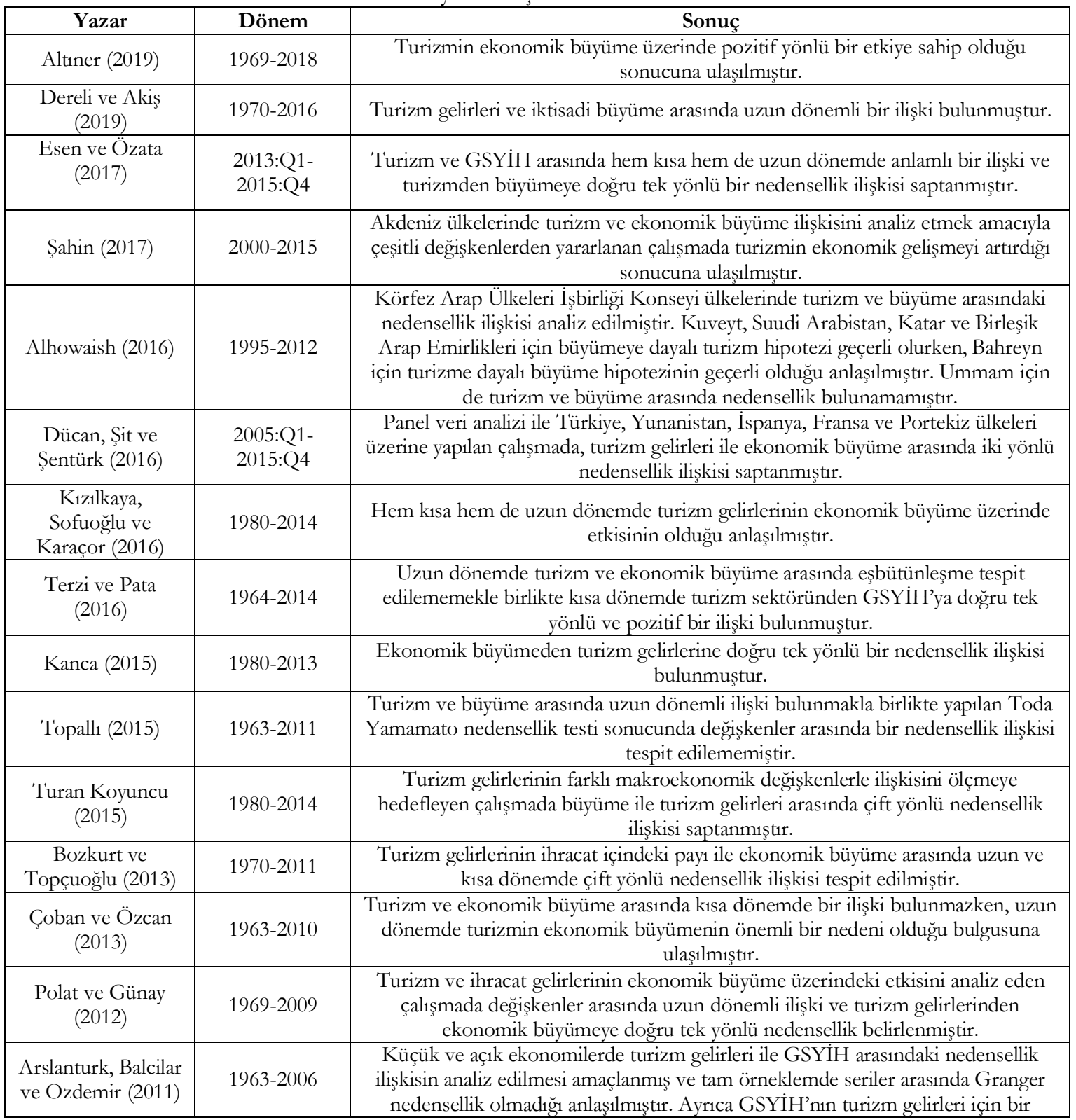




\begin{tabular}{|c|c|c|}
\hline & & $\begin{array}{l}\text { öngörü olmadığı, bununla birlikte turizm gelirlerinin 1980’lerin başından itibaren } \\
\text { GSYİH için olumlu bir öngörücü olduğu ifade edilmiştir. }\end{array}$ \\
\hline $\begin{array}{l}\text { Ekanayake ve } \\
\text { Long (2011) }\end{array}$ & 1995-2009 & $\begin{array}{c}\text { Çalışmada turizme dayalı büyüme hipotezini destekleyecek net kanıtlar } \\
\text { bulunamamakla birlikte turizm gelirlerinin gelişmekte olan ülkelerde ekonomik } \\
\text { büyümeye olumlu katkılar sağladığ ileri sürülmüştür. }\end{array}$ \\
\hline $\begin{array}{c}\text { Samimi, Sadeghi } \\
\text { ve Sadeghi (2011) }\end{array}$ & 1995-2009 & $\begin{array}{l}\text { Gelişmekte olan ülkelerde ekonomik büyüme ile turizm kalkınması arasında ikili } \\
\text { bir nedensellik ve olumlu uzun vadeli bir ilişki olduğu ortaya koyulmuştur. }\end{array}$ \\
\hline Katircioglu (2009) & 1960-2006 & $\begin{array}{l}\text { Türkiye örneğinde turizme dayalı büyüme hipotezi incelenmiştir. Yapılan analiz } \\
\text { sonucunda turizm ve ekonomik büyüme arasında herhangi bir eşbütünleşme } \\
\text { ilişkisi bulunmamıștır. }\end{array}$ \\
\hline $\begin{array}{l}\text { Çetintaş ve Bektaş } \\
\text { (2008) }\end{array}$ & 1964-2006 & $\begin{array}{l}\text { Kısa dönemde turizm ve ekonomik büyüme arasında bir iliş̧ki bulunmazken uzun } \\
\text { dönemde turizmin ekonomik büyümenin önemli bir belirleyicisi olduğu } \\
\text { anlaşılmışır. }\end{array}$ \\
\hline $\begin{array}{l}\text { Lee ve Chang } \\
\text { (2008) }\end{array}$ & 1990-2002 & $\begin{array}{l}\text { Küresel ölçekte GSYİH ile turizm arasında ortak bir ilişki olduğu kanıtlanmıştır. } \\
\text { Ayrıca yapilan panel veri analizi sonucunda turizmin GSYIH üzerindeki etkisinin } \\
\text { OECD üyesi olmayan ülkelerde, OECD ülkelerinden daha büyük olduğu } \\
\text { savunulmustur. }\end{array}$ \\
\hline Bahar (2006) & $1963-2004$ & $\begin{array}{l}\text { Turizm ve büyüme değişkenleri arasında uzun dönemli bir ilişki saptanıp turizmin } \\
\text { ekonomik büyüme üzerinde olumlu bir etkisi olduğu sonucuna ulaşısııștır. }\end{array}$ \\
\hline Çil Yavuz (2006) & $\begin{array}{l}\text { 1992:Q1- } \\
\text { 2004:Q4 }\end{array}$ & Turizm gelirleri ile iktisadi büyüme arasında nedensellik ilişkisi bulunamamıştır. \\
\hline $\begin{array}{l}\text { Gökovalı ve Bahar } \\
\text { (2006) }\end{array}$ & $1987-2002$ & $\begin{array}{c}\text { Akdeniz ülkeleri için turizme dayalı büyüme hipotezi test edilmiştir. Sonuç olarak } \\
\text { turizmin ekonomik büyümeye yardımcı olduğu hipotezi regresyon sonuçlarına } \\
\text { göre doğrulanmıștır. }\end{array}$ \\
\hline
\end{tabular}

Tablo 3 incelendiği zaman literatürde turizm ve büyüme ilişkisinin turizme dayalı büyüme ve büyümeye dayalı turizm şeklinde ayrı ayrı değerlendirildiği görülmüștür. Yapılan literatür incelemesi sonucunda ise Dereli ve Akiş (2019), Samimi, Sadeghi ve Sadeghi (2011) ve Bahar (2006)'da olduğu gibi değişkenler arasında ilişki olduğu sonucuna ulaşılan çalışmalar olduğu gibi Katircioglu (2009) ve Çil Yavuz (2006)'da olduğu gibi ilişkinin bulunmadığ1 çalışmalar da literatürde yer almıştr.

\section{Ekonometrik Analiz ve Bulgular}

Turizm ile büyüme ilişkisini analiz etmeyi amaçlayan çalışmada analizi gerçekleştirebilmek için Türkiye'nin büyüme (GDP), turizm gelirleri (TR) ve yabancı ziyaretçi sayısı (FV) değişkenlerinin 1998:Q1 2019:Q4 dönem verilerinden yararlanılmıştr. Modelde büyüme bağımlı değissken olarak değerlendirilirken turizmi temsil eden turizm gelirleri ve yabancı ziyaretçi sayısı bağımsız değişken olarak ele alınmışır. Ayrıca kullanılan değişkenler yüksek bir veri düzeyine sahip olduğundan dolayı varyans salınımını engelleyebilmek amacıyla tüm değişkenlerin logaritması alınarak işleme tabi tutulmuştur. Diğer yandan büyüme verilerinin elde edilmesinde Türkiye Cumhuriyeti Merkez Bankası Elektronik Veri Dağıtım Sistemi (EVDS) verilerinden yararlanılırken turizm verileri, Türkiye Seyahat Acentaları Birliği (TÜRSAB) istatistiklerinden elde edilmiştir. Analizde ilk olarak değişkenlerin durağan olduğu seviyeyi tespit etmek amacıyla birim kök testi yapılmış ve akabinde Gecikmesi Dağıtılmış Otoregresif Model (ARDL) testi yapılmıştr. En son ise değişkenler arasındaki ilişkinin yönünün tespit edilmesi amacıyla Granger nedensellik testi uygulanmıştır. Granger nedensellik testinin yapılması için de öncelikli olarak seviyede durağan olmayan GDP değişkeninin farkları alınarak seviyede durağan hale getirilmiştir. Bu işlemlerin gerçekleştirilmesinde ise Eviews paket programından yararlanılmıştır.

\subsection{Birim Kök Testi}

Bir serinin uzun dönemde sahip olduğu özellikler, bir önceki dönemde değişkenin aldığı değeri, bu dönemi nasıl etkilediğinin belirlenmesiyle ortaya çıkartılabilmektedir. Bu sebepten herhangi bir serinin nasıl bir süreçten geldiğini anlamak amaciyla serinin her dönemde aldığı değerin daha önceki dönemdeki değerleriyle regresyonunun bulunması gerekmektedir. Bunun için de en yaygin yöntem olan birim kök testleriyle serinin durağan olduğu seviyenin belirlenmesi gerekmektedir (Tarı, 2015, s. 387).

Birim kök testlerinin en yaygın kullanılanların biri de Phillips ve Perron (PP) birim kök testleridir. PP testi Genişletilmiş Dickey-Fuller (ADF) testine benzerlik göstermekle birlikte DF ve ADF testlerinin hata 
terimine ilişkin varsayımlarına göre daha esneklik göstermektedir. Ayrıca DF ve ADF testleri hata teriminin bağımsız ve sabit varyanslı olduğunu kabul etmektedir. Bu metodoloji kullanılırken hata terimleri arasında korelasyon olmadığına ve sabit varyansa sahip olduklarından emin olmak gerekmektedir. PP testi DF'nin hata terimleri ile ilgili olan bu varsayımını genişletmektedir. Diğer yandan DF testindeki bağımsızlık ve homojenite varsayımı PP testinde terk edilmiş onun yerine hata terimlerinin zayıf bağımlılı̆̆1 ve heterojen dağılımı kabul edilmiştir (Tarı, 2015, s. 400). PP yönteminde yer alan denklemler aşağıda verilmiştir (Pata, Yurtkuran ve Kalça, 2016, s. 264):

$Y_{t}=\alpha_{0}+\beta_{1} Y_{t-1}+\mu_{t}$

$Y_{t}=\alpha_{0}+\beta_{1} Y_{t-1}+\beta_{2}(t-T / 2)+\mu_{t}$

Yukanda yer alan (1) ve (2) numaralı denklemler sirasiyla sabitli ve sabitli-trendli modelleri göstermektedir. Modelde; $\left(Y_{t}\right)$ test edilen değişkeni, $\left(\alpha_{0}\right)$ sabit terimi, $(t)$ trendi, $(T)$ gözlem sayısını ve $\left(\mu_{t}\right)$ hata teriminin ifade etmektedir. PP yönteminde test edilecek değer $\beta_{1}$ katsayısı olup ADF yöntemindeki gibi bulunan değer MacKinnon (1996) kritik tablo değeriyle karşılaştırılarak serinin durağan olup olmadı̆̆ına karar verilmektedir. Çalışmada büyüme ile turizm ilişkisini analiz etmeye yönelik kullanılan GDP, TR ve FV değişkenlerine uygulanan PP birim kök testi sonuçları ise Tablo 4'de gösterilmiştir.

Tablo 4. PP Birim Kök Test Sonuçları

\begin{tabular}{|c|c|}
\hline Değişkenler & PP Testi \\
\hline LNGDP & $\begin{array}{r}-3,341 \\
0,066 \\
\end{array}$ \\
\hline LNTR & $\begin{array}{c}-9,349 \\
0,000 \\
\end{array}$ \\
\hline LNFV & $\begin{array}{c}-8,308 \\
0,000 \\
\end{array}$ \\
\hline $\begin{array}{cc}\Delta \text { LNGDP } & \\
& \text { p-değeri }\end{array}$ & $\begin{array}{c}-5,305 \\
0,000 \\
\end{array}$ \\
\hline \multicolumn{2}{|c|}{$\begin{array}{l}\text { Testlerde değişkenler } \% 5 \text { anlamlılık düzeyinde değerlendirilmiştir. } \\
\text { Ayrıca LNGD, LNTR ve LNFV değişkenlerin seviyede ki ; } \\
\Delta \text { LNGDP'de birinci farkında ki değerini göstermektedir. } \\
\mathrm{H}_{0} \text { : Birim kök vardır. } \mathrm{H}_{1} \text { : Birim kök yoktur. }\end{array}$} \\
\hline
\end{tabular}

Değişkenler iktisadi modellerde en çok kabul gören \%5 anlamlılık düzeyinde Phillips ve Perron (PP) değerlerine bakılarak analiz edilmiştir. Analizde büyümeyi temsil eden LNGDP değişkeninin birinci farkında durağan olduğu yani I (1) olduğu anlaşılmıştır. Bağımsız değişkenlerden LNTR ve LNFV değişkeninin ise seviyede durağan olduğu yani I (0) olduğu tespit edilmiştir. Elde edilen sonuçlar doğrultusunda da değişkenlerin uzun dönemli ilişkilerinin analiz edilebilmesi için eşbütünleşme analizinin yapılması gerekmektedir. Ancak çalışma kapsamında analiz edilen üç değişkenin birbirinden farklı seviyelerde durağan olması ARDL analizinin yapılmasını zorunlu kılmaktadır. Çünkü ARDL analizi bağımlı değişkenin I (1), bağımsız değişkenlerin ise farklı seviyelerde durağan olma özelliği gösterdiği durumlarda değişkenlerin analiz edilmesine olanak sağlayan bir test özelliği sergilemektedir. Dolayısıyla çalışmanın bundan sonraki kısmına ARDL analizi ile devam edilmektedir.

\subsection{ARDL Analizi Yaklaşımı}

Seriler arasında eşbütünleşme ilişkisinin tespit edilmesinde yaygın olarak Engle ve Granger (1987), Johansen (1988), Johansen ve Juselius (1990) tarafindan geliştirilen yöntemler kullanılabilmektedir. Ancak Engle ve Granger yöntemi ikiden daha fazla değişken olduğu durumlarda birden fazla eşbütünleşme ilişkisi olabileceğinden dolayı çok fazla tercih edilmemektedir. Johansen, Johansen ve Juselius testlerinde ise tüm serilerin seviyede durağan olmamaları ve aynı derecede farkı alındığında durağan olmaları gerekmektedir. Klasik eşbütünleşme testlerinde ortaya çıkan bu kısıtlamalar Gecikmesi Dağıtılmış Otoregresif Model’i (ARDL) sınır testi yaklaşımının ortaya çıkmasına neden olmuştur (Koçak, 2014, s. 68).

ARDL sınır testi yaklaşımının bu bağlamda, alternatif eşbütünleşme testlerine göre bazı avantajlanı bulunmaktadır. En önemli avantajı ise analize dâhil edilen değişkenlerin I (0) ya da I (1) olup olmamasına bakılmaksızın uygulanabilmesidir. ARDL analizinin bu özelliği, önsel olarak değişkenlerin bütünleşme 
derecelerini belirleme zorunluluğunu ortadan kaldırmaktadır. Ayrıca birim kök testlerinin gücü düşük olduğunda, özellikle ön testin problemli sonuçlar doğurma ihtimali bulunmaktadır. Sınır testi yaklaşımının bu bağlamda bir diğer avantajı kısıtsız hata düzeltme modeli (UECM) kullanıldığında Engle-Granger yöntemine göre daha iyi istatistiksel özelliklere sahip olmaktadır. Diğer önemli avantajı ise küçük veya sınırlı örnek kümeleri için oldukça etkin bir şekilde uygulanabilmektedir. Çünkü gözlem sayısı az olduğu durumlarda Engle-Granger ve Johansen eşbütünleşme testleriyle kıyaslandığında daha güvenilir sonuçlar ortaya çıkarmaktadır (Pamuk ve Bektaş, 2014, s. 82). ARDL yöntemi temelde üç aşamadan oluşmaktadır. İlk aşamada değişkenler arasındaki uzun dönem ilişkisinin olup olmadığını test etmek için yapılan sınır testi yer almaktadır. ARDL sınır testi için uygulanacak denklem aşağıdaki gibidir (Görüş ve Türköz, 2016, s. 39):

$\Delta Y_{t}=\alpha_{0}+\sum_{i=1}^{m} \alpha_{1 i} \Delta Y_{t-i}+\sum_{i=0}^{m} \alpha_{2 i} \Delta X_{t-i}+\alpha_{3} Y_{t-1}+\alpha_{4} X_{t-1}+\mu_{t}$

Eşbütünleşme ilişkisinin varlığının test edilebilmesi için değişkenlerin birinci dönem gecikmelerine $F$ testi yapılmaktadır. Burada ilgili kritik değer Pesaran vd. (2001) tarafindan tablolaştırılmıștır. Hesaplanan Fistatistik değeri Peseran (2001)'deki alt ve üst kritik tablo değerleri ile karşılaştırılarak bir sonuca varılmaktadır. Hesaplanan F-istatistik değeri alt ve üst sınır dışındaysa değişkenlerin eşbütünleşik olup olmamalarına dair bir çıkarımda bulunulabilmektedir. Ĕger hesaplanan $\mathrm{F}$ istatistik değeri üst kritik değerinden büyük ise değişkenler arasında eşbütünleşme ilişsisi olmadığını gösteren temel hipotez reddedilirken değişkenler arasında eşbütünleşme ilişkisi olduğu sonucuna ulaşılmaktadır. Hesaplanan Fistatistik değeri alt kritik değerinden küçük çıkarsa da temel hipotez reddedilememekte ve seriler arasında eşbütünleşme olmadığı sonucuna ulaşılmaktadır. Son olarak hesaplanan F-istatistiği alt kritik değer ile üst kritik değer arasındaysa kesin bir yorum yapılamamakta ve değişkenlerin durağanlık seviyelerini dikkate alan diğer eşbütünleşme yöntemlerine başvurulması gerekmektedir (Gülmez, 2015, ss. 146-147).

Yukarıda yer alan (3) numaralı denklemde (t) trend değişkenini, $(\mathrm{m})$ ise gecikme uzunluğunu temsil etmektedir. Bu ARDL analizinin gerçekleştirilebilmesi için uygun gecikme uzunluğunun belirlenmesi gerektiğini göstermektedir. Gecikme sayısının belirlenebilmesi için Akaike, Schwarz ve Hannan-Quinn gibi kritik değerlerinden faydalanılmaktadır (Karagöl, Erbaykal ve Ertuğrul, 2007, s. 76). Ancak bu noktada modelin otokorelasyon içerip içermediği gibi tanısal testlerin yapılması da önem arz etmektedir.

Yapılan sınır testi sonuçlarında eğer değişkenler arasında eşbütünleşme ilişkisi tespit edilirse, değişkenlerin uzun ve kısa dönem parametrelerinin hesaplanarak yorumlanması gerekmektedir. Çünkü uzun dönem ilişkisinin tespiti bu analizin yapılmasına olanak sağlamaktadır. Yapılan bu uzun ve kısa dönemli analizlerin yorumları ise ARDL modelinin ikinci ve üçüncü aşamasını oluşturmaktadır. ARDL analizinin ikinci aşamasını oluşturan uzun dönem modeli şu şekilde kurulabilmektedir (Erdoğan ve Bozkurt, 2008, s. 30):

$Y_{t}=\alpha_{0}+\sum_{i=1}^{m} \alpha_{1 i} Y_{t-i}+\sum_{i=0}^{n} \alpha_{2 i} X_{t-i}+\mu_{t}$

Uzun dönemli model kurulduktan sonra ARDL analizinin üçüncü aşaması olan kısa dönem ilişkisi tahmin edilmektedir. Kısa dönem ilişkisi tahmin edilirken, uzun dönem ilişkisinden elde edilen hata terimi modelinden yararlanılmakta ve hata teriminin bir dönem gecikmeli değeri kullanılmaktadır. Kısa dönem ilişkisi, hata düzeltme modeli ile aşağıdaki gibi modellenmektedir (Gülmez, 2015, s. 147):

$\Delta Y_{t}=\alpha_{0}+\sum_{i=1}^{m} \alpha_{1 i} \Delta Y_{t-i}+\sum_{i=0}^{n} \alpha_{2 i} \Delta X_{t-i}+\beta H D T_{t-1}+\mu_{t}$

(5) numaralı eşitlikte, uzun dönem eșitliğinden elde edilen ve kısa dönem dengesizliğinin ne kadarının uzun dönemde giderileceğini ifade eden hata teriminin gecikmeli değerine ilişkin katsayının istatistiki olarak anlamlı ve negatif olması beklenmektedir. Modelde (HDT) ile gösterilen değişken hata düzeltme terimini sembolize etmektedir. Hata düzeltme katsayısının 0 ile -1 arasında olması durumunda uzun dönem denge değerine tekdüze bir şekilde yakınlaşma olduğu anlaşılmaktadır. Katsayının -1 ile -2 değerleri arasında yer alması hata düzeltme aşamasının uzun dönem denge değerleri etrafında, azalan dalgalanmalar göstererek 
dengeye ulaştı̆̆ını göstermektedir. Son olarak bu değerin pozitif ya da -2 'den küçük olması, dengeden uzaklaşıldığ anlamına gelmektedir.

ARDL analizine başlanılmadan önce ilk olarak uygun gecikme uzunluğunun belirlenmesi gerektiği için analize ilk gecikme uzunluğunun tespitiyle başlanılmıss ve elde edilen sonuçlar Tablo 5'de gösterilmiştir.

Tablo 5. ARDL Analizi için Uygun Gecikme Uzunluğu

\begin{tabular}{|c|c|c|c|c|c|}
\hline Gecikme Say1s1 & LR & FPE & AIC & SC & HQ \\
\hline 0 & NA & 0,042 & 5,347 & 5,437 & 5,383 \\
\hline 1 & 615,242 & 1,610 & $-2,522$ & $-2,165$ & $-2,379$ \\
\hline 2 & 123,444 & 3,720 & $-3,988$ & $-3,363$ & $-3,737$ \\
\hline 3 & 100,265 & 1,120 & $-5,195$ & $-4,302$ & $-4,837$ \\
\hline 4 & 87,334 & 3,810 & $-6,274$ & $-5,113$ & $-5,808$ \\
\hline $\mathbf{5}$ & $\mathbf{3 2 , 4 3 7 *}$ & $\mathbf{2 , 9 0 0 *}$ & $\mathbf{- 6 , 5 5 6 *}$ & $\mathbf{- 5 , 1 2 7} *$ & $\mathbf{- 5 , 9 8 3}$ \\
\hline 6 & 7,881 & 3,230 & $-6,460$ & $-4,763$ & $-5,780$ \\
\hline 7 & 12,598 & 3,300 & $-6,452$ & $-4,487$ & $-5,664$ \\
\hline 8 & 14,747 & 3,230 & $-6,495$ & $-4,262$ & $-5,600$ \\
\hline
\end{tabular}

Tablo 5'e bakıldığı zaman tüm kriter değerlerinde ARDL analizi için en uygun gecikme uzunluğunun 5 olduğu anlaşılmıştır. Dolayısıyla gerçekleştirilecek ARDL analizinde gecikme uzunlukları 5 olarak ele alınmış ve analiz gerçekleştirilmiştir. Ancak öncelikli olarak yapılan analiz kapsamında oluşturan ARDL modeline ait bazı tanisal testlerin yapılması gerekmektedir. Yapılan bu testler modelde otokorelasyon sorunu olup olmaması gibi bir takım testlerin yapılması anlamına gelmekte ve modelin geçerliliğini doğrulamaktadır. Bu kapsamda serilerin otokorelasyon içerip içermediğini anlamak için Breusch-Godfrey Serisel Korelasyon LM ve model kurma hatası olup olmadığını anlamak için de Ramsey Reset test sonuçları incelenmiştir. Yapılan bu testlerin sonuçları Tablo 6'da gösterilmiştir.

Tablo 6. Tanısal Test Sonuçları

\begin{tabular}{|l|c|c|}
\hline \multicolumn{1}{|c|}{ Tanısal Testler } & F-istatistik Değeri & Olasılik Değeri \\
\hline Breusch-Godfrey Serisel Korelasyon LM test & 0,055 & 0,938 \\
\hline Ramsey Reset Test & 0,645 & 0,424 \\
\hline
\end{tabular}

Breusch-Godfrey Serisel Korelasyon LM test sonuçlarına bakıldığı zaman \%5 anlamlılık düzeyinde serisel korelasyon olmadığın ifade eden yokluk hipotezi reddedilememektedir. Dolayısıyla test sonucunda otokorelasyon olmadığı sonucuna ulaşılmaktadır. Ayrıca analizde model kurma hatası olup olmadığını anlayabilmek için Ramsey Reset Test yapılmıştır. Yapılan analiz sonucunda olasılık değerinin \% 5 düzeyinden büyük olması çalışmada model kurma hatası olmadığını göstermiştir. Ayrıca çalışmada serilerde yapısal kırılma olup olmadığını anlayabilmek için Cusum ve Cusum-SQ test’i yapılmıştır. Yapılan test sonuçları Şekil 1'de gösterilmiştir.
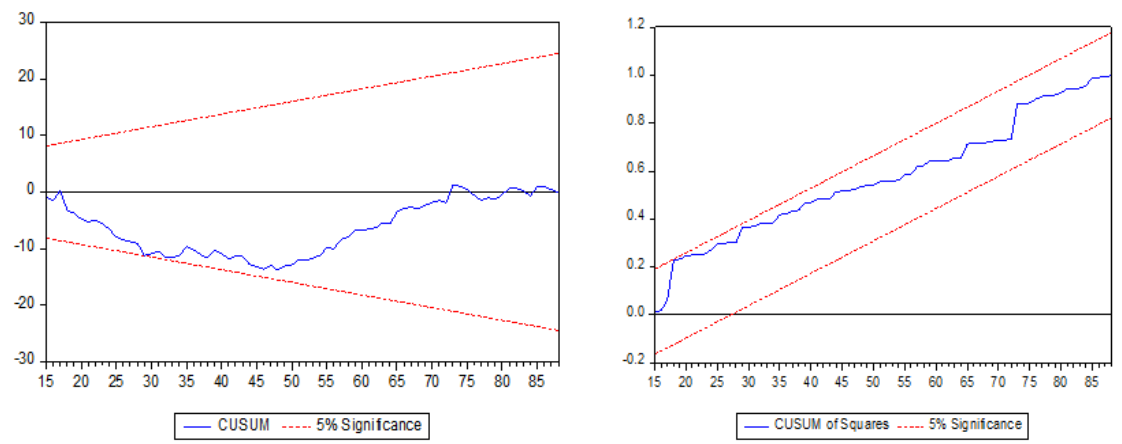

Şekil 1. Cusum ve Cusum-SQ Test Sonuçları

Şekil 1'e bakıldığ1 zaman veri setinin güvenli bir bant aralığında yer aldığ1 görülmektedir. Bu sonuç, yani Şekil 1'de görüldüğ̈̈ gibi bir sapma olmaması, veri setinde yapısal kırılma olmadığını göstermektedir. Tablo 6'dan ve Şekil 1'den elde edilen sonuçlar doğrultusunda modelde genel olarak bir sorun olmadığ1 
anlaşıldığından dolayı değişkenler arasındaki uzun dönemli ilişkinin analiz edilebilmesi için ARDL sınır testi uygulanmıştır. Elde edilen sonuçlar ise Tablo 7'de gösterilmiştir.

Tablo 7. ARDL Sinır Testi Sonuçları

\begin{tabular}{|c|c|c|c|}
\hline $\mathbf{K}$ & F-istatistik & Alt Sinır & Üst Sınır \\
\hline 2 & 23,75 & 3,1 & 3,87 \\
\hline \multicolumn{2}{|c|}{ Değişkenler $\% 5$ anlamlılık düzeyinde değerlendirilmiştir ve K bağımsız değişken sayısını göstermektedir. } \\
\hline
\end{tabular}

Tablo 7’ye bakıldığ1 zaman F-istatistik değerinin üst sınırın üzerinde bir değer aldığ1 görülmektedir. Bu sonuç değişkenler arasında uzun dönemli bir ilişki olduğunu ortaya koymaktadır. Yani literatürde belirtilen, turizm ve büyüme arasında olumlu yönde bir ilişki olduğu varsayımı doğrulanmaktadır. Yapılan sınır testi analizi sonucunda değişkenler arasında uzun dönemli bir ilişki çıktığından dolayı değişkenlerin uzun ve kısa dönemli katsayılarına bakılması da çalıșma kapsamında gerekli görülmüștür. Bu bağlamda ilk olarak ARDL analizi sonucunda elde edilen uzun dönem katsayıları incelenmiş ve elde edilen sonuçlar Tablo 8'de verilmiştir.

Tablo 8. ARDL Modeli Uzun Dönemli Analiz Sonuçları

\begin{tabular}{|c|c|c|c|}
\hline \multicolumn{4}{|c|}{ Uzun Dönem Katsayıları } \\
\hline Değişkenler & Katsayılar & T-istatistik Değerleri & Olasıl1k Değerleri \\
\hline LNFV & 6,462 & 1,867 & 0,065 \\
\hline LNTR & $-5,817$ & $-1,382$ & 0,170 \\
\hline
\end{tabular}

Uzun dönem katsayılarının tahmininde yabancı ziyaretçi sayısını ifade eden LNFV değişkeninden büyümeye doğru pozitif ve \%10 düzeyinde istatistiksel olarak anlamlı bir nedensellik ilişkisi tespit edilmiştir. Elde edilen sonuç, uzun dönemde yabancı ziyaretçi sayısında meydana gelecek \%1'lik bir artışın büyümeyi \% 6,462 oranında artıracağını ortaya koymuştur. Diğer yandan turizm gelirlerini ifade eden LNTR değişkeninde ise istatistiksel olarak anlamlı bir sonuç elde edilememiştir. Bundan dolayı da turizm gelirlerinin büyüme üzerindeki etkisi yorumlanamamıştur. ARDL modeli kapsamında değişkenlerin uzun dönemli katsayıları incelendikten sonra kısa dönemli ilişkileri de incelenmiş ve sonuçlar Tablo 9'da açıkça gösterilmiştir.

Tablo 9. ARDL Modeli Kısa Dönemli Analiz Sonuçları

\begin{tabular}{|c|c|c|c|}
\hline \multicolumn{4}{|c|}{ Hata Düzeltme Modeli } \\
\hline Değişkenler & Katsayılar & T-istatistik Değerleri & Olasıllk Değerleri \\
\hline D(LNTR) & $-0,006$ & $-0,126$ & 0,899 \\
\hline D(LNTR(-1)) & $-0,006$ & $-0,207$ & 0,836 \\
\hline D(LNTR(-2)) & 0,020 & 0,712 & 0,478 \\
\hline D(LNTR(-3)) & $-0,056$ & $-1,760$ & 0,082 \\
\hline D(LNTR(-4)) & $-0,148$ & $-3,450$ & 0,000 \\
\hline ECM (-1) & $-0,022$ & $-9,942$ & 0,000 \\
\hline
\end{tabular}

Hata Düzeltme Modelinde (ECM), değişkenin katsayısının negatif ve istatistiksel olarak anlamlı olması gerekmektedir. Ancak bu şartlar sağlandığında hata düzeltme modeli çalışmakta aksi halde hata düzeltme modelinin çalışmadığı sonucuna ulaşılmaktadır. Tablo 9'a bakıldığı zaman hata düzeltme değişkeninin katsayısının negatif olduğu ve olasıllk değerinin de 0,05 değerinden küçük olduğu görülmektedir. Bu katsayının anlamlı olduğunu ve hata düzeltme modelinin çalıştı̆̆ını göstermektedir. Ayrıca Tablo 9'da yer alan hata düzeltme modeli katsayısına bakıldığı zaman -0,022 olduğu görülmektedir. Hata düzeltme değişkeninin katsayının bu şekilde 0 ile -1 arasında bir değer alması sistemde, uzun dönem denge değerine tekdüze bir yakınlaşma olduğunu göstermektedir. Yani kısa vadede meydana gelen dengesizlikler sonraki dönemlerde düzelebilecektir. Kısa vadede yaşanan dalgalanmaların uzun dönem değerine yakınsama süreci $1 /|-0,022|=45,45$ dönem sürmektedir. 


\subsection{Granger Nedensellik Testi}

Ekonometrik analizlerde bir değişkenin diğer değişkenlerle ilişkisi söz konusu olabilmektedir. Buna karşın değişkenler arasındaki ilişki bağlllığı bu değişkenler arasında mutlak bir nedensellik ilişkisi olduğu anlamına gelmemektedir. Bu sebepten değişkenler arasındaki ilişkinin net olarak anlaşılabilmesi için değişkenlerin bir nedensellik testine tabi tutulması gerekmektedir. Uygulamalı ekonometrik analizlerde, zaman serileri arasındaki ilişkinin tespit edilebilmesi için en sık kullanılan yöntem Granger (1969) tarafından geliştirilen nedensellik analizidir (Gül ve Yavuz, 2011, s. 79). Granger nedensellik testi iki denklem kullanılarak yapılmaktadır. Bu denklemler aşağıda gösterilmiştir (Bağdiken ve Beşer, 2009, s. 9):

$Y_{t}=\alpha_{0}+\sum_{i=1}^{m} \alpha_{i} Y_{t-i}+\sum_{j=1}^{m} \beta_{j} X_{t-j}+\mu_{1 t}$

$X_{t}=\alpha_{0}+\sum_{i=1}^{m} \lambda_{i} X_{t-i}+\sum_{j=1}^{m} \delta_{j} Y_{t-j}+\mu_{2 t}$

Denklemlerde (m) gecikme uzunluğunu ifade etmekte olup $\left(\mu_{1 t}\right)$ ve $\left(\mu_{2 t}\right)$ hata terimlerinin birbirinden bağımsız oldukları (White noise-Beyaz gürültü) varsayılmaktadır. Denklem (6) X'ten Y'ye $(X \rightarrow Y)$ doğru nedensellik ilişkisini, denklem (7) ise Y'den $\mathrm{X}^{\prime} \mathrm{Y}(\mathrm{Y} \rightarrow \mathrm{X})$ doğru nedensellik ilişkisini göstermektedir. Bir diğer ifadeyle (6) no'lu denklemde $(\beta)$ ' lar topluca anlamlı, (7) no'lu denklemdeki ( $\delta)^{\prime}$ ler topluca anlamsız ise $(\mathrm{X} \rightarrow \mathrm{Y}$ ) doğru bir ilişki bulunmaktadır. Tam tersi (6) no'lu denklemde ( $\beta$ )' lar anlamsız, (7) no'lu denklemdeki ( $\delta)^{\prime}$ ler anlamlı ise $(\mathrm{Y} \rightarrow \mathrm{X}$ ) doğru tek yönlü bir ilişkinin varlığından söz edilebilmektedir. Ancak burada her ikisinin anlamlı ve her ikisinin de anlamsız olduğu bir durumda söz konusu olabilmektedir. Böyle bir durumda eğer $(\beta)$ ve $(\delta)^{\prime}$ lerin her ikisi de anlamlı ise $(\mathrm{X} \leftrightarrow \mathrm{Y}) \mathrm{X}$ ve $\mathrm{Y}$ arasında çift yönlü bir ilişki olduğu anlaşılmaktadır. Bu durumun aksine $(\beta)$ ve $(\delta)^{\prime}$ 'lerin her ikisi de anlamsız ise $(\mathrm{X}-\mathrm{Y})$ değişkenler arasında herhangi bir ilişki olmadı̆̆ı sonucuna ulaşılmaktadır. Burada denklem (6)'da önce bağıml değişken uygun gecikme sayısı ile modele dâhil edilmekte ve sonra diğer değişkende aynı gecikme sayısı ile modele katılmakta ve bu modele ait hata kareleri toplamlar1 bulunmaktadir. Daha sonra Wald tarafından geliştirilen F-istatistiği hesaplanmaktadır (Göktaş Yılmaz, 2005, ss. 70-71):

$\mathrm{F}_{(\mathrm{m} ; \mathrm{n}-2 \mathrm{~m})}=\frac{\left(\mathrm{ESS}_{\mathrm{r}}-\mathrm{ESS}_{\mathrm{ur}}\right) / \mathrm{m}}{\left(\mathrm{ESS}_{\mathrm{ur}}\right) / \mathrm{n}-2 \mathrm{~m}}$

Denklem (8)'de (ESS) hata kareler toplamını, (ur) sınırlandırılmamış modeli ve (r) sınırlandırılmış modeli temsil etmektedir. Burada hesaplanan F-istatistiği ( $\mathrm{m}$; n-2m), seçilmiş bir anlamlllık düzeyinde ve serbestlik derecesindeki F-tablo değeriyle kıyaslanılarak sonuca varılmaktadır. Hesaplanan değer, tablo değerinden büyük ise $\left(\mathrm{H}_{0}\right)$ hipotezi kabul edilmemekte, küçük ise kabul edilmektedir. Bu hipotezin reddedilmesi modelde yer alan katsayılann anlamlı olduğunu ifade etmektedir. Bu çalışmada turizm gelirleri, yabancı ziyaretçi sayısı ve ekonomik büyüme arasındaki nedensellik ilişkisinin tespit edilebilmesi için uygulanan Granger nedensellik testi sonuçları Tablo 10'da gösterilmiştir.

Tablo 10. Granger Nedensellik Testi

\begin{tabular}{|c|c|c|c|}
\hline Hipotez $\left(\mathrm{H}_{0}\right)$ & F-istatistiği & Olasıl1k (p) & Sonuç \\
\hline$\triangle \mathrm{LNGDP}, \mathrm{LNFV}$ 'nin Granger nedeni değildir. & 0,324 & 0,896 & Kabul \\
\hline LNFV, $\Delta$ LNGDP'nin Granger nedeni değildir. & 3,107 & 0,013 & Red \\
\hline$\Delta$ LNGDP, LNTR'nin Granger nedeni değildir. & 1,078 & 0,379 & Kabul \\
\hline LNTR, $\Delta$ LNGDP'nin Granger nedeni değildir. & 4,045 & 0,002 & Red \\
\hline LNFV, LNTR'nin Granger nedeni değildir. & 4,689 & 0,000 & Red \\
\hline LNTR, LNFV'nin Granger nedeni değildir. & 4,689 & 0,000 & Red \\
\hline
\end{tabular}

Tablo 10'da değişkenler arasındaki Granger nedensellik ilişkisi gösterilmiştir. Granger nedensellik testi değişkenler arasındaki nedensellik ilişkisinin yönünü ortaya koymaktadır. Elde edilen sonuçlar incelendiğinde yabancı ziyaretçi sayısının ve turizm gelirlerinin $\% 5$ anlamlllık düzeyinde büyümenin Granger nedeni olduğu anlaşılmıştır. Ayrıca turizm gelirleri ile yabancı ziyaretçi sayısı arasında da çift yönlü bir nedensellik ilişkisi olduğu dolayısıyla her iki değişkenin de birbiri üzerinde etkili olduğu sonucuna ulaşılmıştır. 


\section{Sonuç}

Bu çalsşmada Türkiye ekonomisi için 1998:Q1-2019:Q4 dönemine ait verilerden yararlanılarak turizm ve büyüme ilişkisi analiz edilmiştir. Çalışmada turizm göstergeleri olarak turizm gelirleri ve ülkeye gelen yabancı ziyaretçi sayısı verilerinden yararlanılırken ekonomik büyüme verisi olarak gayrisafi yurtiçi hasıla verileri kullanılmıstır. Çalışmada analizi gerçekleştirebilmek amacıyla öncelikli olarak değişkenler PP durağanlık testine tabi tutulmuş ve değişkenlerin farklı seviyelerde durağan olduğu anlaşılmıştır. Birim kök testi sonucunda değişkenler farklı seviyelerde durağan olduğundan dolayı değişkenler arasındaki uzun dönemli ilişki ARDL metodu kapsamında incelenmiştir. Yapılan ARDL analizi kapsamında, Dereli ve Akiş (2019) ve Bahar (2006)'nın çalışmalarına benzer olarak, değişkenler arasında uzun dönemli bir ilişki olduğu anlaşılmıştır. Elde edilen bu sonuçlar Katircioglu (2009)'un çalışmasından elde edilen sonuçlara da ters düşmüştür. Ancak çalışmada değişkenler arasında eşbütünleşme ilişkisi tespit edildiğinden hata düzeltme modeli kapsamında kısa dönemli ilişkileri de analiz edilmiştir. Yapılan kısa dönemli analiz ile birlikte katsayının 0 ile -1 arasında bir değer aldığı görülmüş ve kısa vadede meydana gelen dengesizliklerin sonraki dönemlerde düzelebileceği anlaşılmıştır. En son ise Granger nedensellik testi yapılarak değişkenler arasındaki ilişkinin nedensellik yönü incelenmiştir. Granger nedensellik testi sonunda ise yabancı ziyaretçi sayısının ve turizm gelirlerinin büyümenin bir Granger nedeni olduğu anlaşılmışır. Ayrıca turizm gelirleri ile yabancı ziyaretçi sayısı arasında çift yönlü bir nedensellik ilişkisi de tespit edilmiştir.

Ulaşılan bu ampirik sonuçlara göre, turizm ve büyüme arasında pozitif yönlü bir ilişki olduğu bundan dolayı da literatürde belirtildiği gibi ülke ekonomilerinin gelişmesi ve kalkınabilmesi için turizm sektörünün büyük bir önem arz ettiği sonucuna ulaşılmıştır. Bundan dolayı özellikle Türkiye gibi gelişmekte olan ülkelerin kalkınarak gelişmiş ülkeler arasına girebilmesi için turizm sektörüne ağıllık vermesi ve bu sektörün geliştirilmesine yönelik çalışmalar yapılması büyük bir öneme sahip olmaktadır. Bu doğrultuda ise ülkelerin; ulaşım olanaklarının geliştirilmesi, ülkeye turist çekecek sosyal alanların ve ikame olanaklarının geliştirilmesi, seyahat özgürlügünün artırlmas1, her gelir düzeyine sahip insanlara hitap edebilecek tatil olanaklarının geliştirilmesi gibi politikaların eklenilmesinin uygun bir karar olacağı düşünülmektedir. Ayrıca ülkeye gelecek yerli ve yabancı turistlerin sadece eğlence amaçlı değil de sağllk, eğitim, kültür, din gibi çeşitli turistik sebeplerden gelebileceği de düşünülecek olursa özellikle ülke içerisinde eğitim ve kültür düzeyinin artırllması, turistlere sosyal güvenlik ve sağlı güvencesinin verilmesi de ülkeye gelen turist sayısının artmasında etkili olacaktır. Bu doğrultuda literatüre katkı sağlaması amacıyla bundan sonraki yapılacak çalışmalar da turizm sektörünün sağlık, eğitim, din ve eğlence turizmi olarak ayrı ayrı değerlendirilip analiz edilerek, ülke içerisinde özellikle hangi turizm alanının etkili olacağının tespit edilmesinin literatüre önemli kazanımlar sağlayacağı düşünülmektedir.

\section{Extended Abstract}

The tourism sector is among the sectors that develop rapidly in the gross domestic product and have a very high growth capacity. Turkey made progress since the 1980s in the sector, especially in the closing of the current account deficit, increasing employment opportunities; the creation of foreign exchange earnings and payments to countries plays an important role in improving the balance. Therefore, talking about the importance and share of the tourism sector in the development of a country is possible by measuring the economic effects of tourism. Therefore, analyzing the impact of the tourism sector on the economy is one of the most extensive topics in the literature. In this way, the most prominent analysis has been the relationship between tourism and growth being the most basic indicator of economic development.

This study aims to analyze the relationship between tourism and growth in Turkey. Three different variables are used in the study to perform the analysis. While gross domestic product among these variables represents growth, tourism revenues and number of foreign visitors are used to represent tourism. In the analysis, the data of the variables between the years 1998:Q1-2019:Q4 are used. Due to the high value of the data in the analysis, in order to prevent the variance oscillation, the variables are processed by taking the natural logarithms. In order to choose the most accurate econometric method in analyzing the relationship between tourism and growth, and thus to reach the most accurate result, firstly, the Phillips and Perron unit root tests are applied to all variables. As a result of test, it is understood that 
the variables of growth are stationary at the first difference, while tourism revenues and number of foreign visitors are stationary at level. These results show that the most accurate method to be used in determining the relationship between tourism and growth is the Autoregressive Distributed Lag Test (ARDL). ARDL analysis allows the analysis of the relationship between the estimators when the variables are stationary at different levels.

In order to perform ARDL analysis, it is necessary to determine the most appropriate lag length for analysis. Accordingly, various criteria values such as Final Prediction Error (FPE), Akaike (AIC), Schwarz (SC) and Hannan-Quinn (HQ) are used. In the study, it has been shown that the most suitable lag length for ARDL analysis is 5 in all criterion values. Therefore, 5 is chosen as the appropriate lag length for ARDL analysis. Later, some diagnostic tests are applied and it is understood that the established model is not contain autocorrelation. In addition, Ramsey Reset Test is performed to see if there is any model creation error in the analysis. As a result of the analysis, it is seen that there is no modeling error in the study. In addition, Cusum and Cusum-SQ tests are conducted to determine whether there is a structural break in the series. As a result of the test, it is understood that there is no structural break in the data set. As a result of the ARDL bounds test, it is concluded that there is a long-term relationship between variables. As a result of the interpretation of the long-term coefficients, it is revealed that a $1 \%$ increase in the number of foreign visitors in the long term will increase the growth by $6,462 \%$. On the other hand, the effect of tourism revenues on growth could not be interpreted as a statistically significant result could not be obtained. These results also made it possible to examine the short-term relationships of the variables. In this way, error correction model has been applied. As a result of the analysis, it is seen that the coefficient of the error correction variable took a value between 0 and -1 . This situation shows that there is a uniform convergence to the long-term equilibrium value in the system. In other words, imbalances that occur in the short term can be corrected in the future. In addition, in the study, the convergence process of short-term fluctuations to long-term value $1 /|-0,022|=45,45$ semesters.

In econometric analysis, the relationship of a variable with other variables can be discussed in this way. However, this does not mean that there is an absolute causal relationship between variables. Therefore, Granger causality test is applied to variables in order to understand the relationship between variables clearly. According to the results obtained from the Granger causality test, it is understood that the number of foreign visitors and tourism revenues are the Granger reasons for growth. In addition, it was concluded that there is a bidirectional causality relationship between tourism revenues and the number of foreign visitors, so both variables are effective on each other. According to these results, it is understood that there is a positive relationship between tourism and growth and therefore the tourism sector is of great importance for the development of the national economies.

\section{Kaynakça}

Akar, A. (2020). Sağhk turizmi kapsamında termal oteller ve dıs turizm talebinin yapısal analizi: Aydın ili örneği. Yayımlanmamış yüksek lisans tezi, Aydın Adnan Menderes Üniversitesi Sağlık Bilimleri Enstitüsü, Aydın.

Akın, A., Şimşek, M. Y. \& Akın, A. (2012). Turizm Sektörünün Ekonomideki Yeri ve Önemi. Akademike Arastırmalar ve Calısmalar Dergisi, 4(7), 63-81.

Alhowaish, A. K. (2016). Is Tourism Development a Sustainable Economic Growth Strategy in the Long Run? Evidence from GCC Countries. Sustainability, 8(7), 605.

Altuner, A. (2019). Turizm ve Ekonomik Büyüme İlişkisi: Türkiye Örneği (1969-2018). Anadolu İktisat ve İsletme Dergisi, 3(2), 114-133.

Arslanturk, Y., Balcilar, M. \& Ozdemir, Z. A. (2011). Time-Varying Linkages Between Tourism Receipts and Economic Growth in a Open Economy. Economic Modelling, 28, 664-671.

Bağdiken, M. \& Beşer, B. (2009). Ekonomik Büyüme ile Kamu Harcamaları Arasındaki Nedensellik İlişkisinin Wagner Tezi Kapsamında Bir Analizi: Türkiye Örneği. ZKÜ Sosyal Bilimler Dergisi, 5(9), 1-17.

Bahar, O. (2006). Turizm Sektörünün Türkiye’nin Ekonomik Büyümesi Üzerindeki Etkisi: VAR Analizi Yaklaşımı. Yönetim ve Ekonomi, 13(2), 137-150.

Bilgiçli, İ. \& Altınkaynak, F. (2016). Turizm Endüstrisinin Türkiye Ekonomisi İçindeki Yeri ve Önemi; Ekonomi Paradigmasıyla Yaklaşım. Uluslararası Yönetim İktisat ve İsletme Dergisi, 16, 560-580. 
Bozgeyik, Y. \& Yoloğlu, Y. (2015). Türkiye’de Turizm Gelirleri ile GSYH Arasındaki İlişki: 2002-2014 Dönemi. Uluslararası Sosyal Arastirmalar Dergisi, 8(40), 627-640.

Bozkurt, E. \& Topçuoğlu, Ö. (2013). Türkiye'de Ekonomik Büyüme ve Turizm İlişkisi. Gümüşhane Üniversitesi Sosyal Bilimler Elektronik. Dergisi, 7, 91-105.

Çeken, H. (2008). Turizmin Bölgesel Kalkınmaya Etkisi Üzerine Teorik Bir İnceleme. Afton Kocatepe Üniversitesi İ.I.B.F. Dergisi, 10(2), 293-306.

Çeken, H. \& Ateşoğlu, L. (2008). Küreselleşme Sürecinde Turizm Endüstrisinin Avrupa Birliği ve Türkiye Ekonomisindeki Yeri ve Önemi. Ticaret ve Turižm Ë̆itim Fakültesi Dergisi, 1, 136-151.

Çetintaş, H. \& Bektaş, Ç. (2008). Türkiye'de Turizm ve Ekonomik Büyüme Arasındaki Kısa ve Uzun

Dönemli İlişkiler. Anatolia: Turižm Araştrmalar Dergisi, 19(1), 37-44.

Çil Yavuz, N. (2006). Türkiye'de Turizm Gelirlerinin Ekonomik Büyümeye Etkisinin Testi: Yapısal

Kır1lma ve Nedensellik Analizi. Doğus Üniversitesi Dergisi, 7(2), 162-171.

Çoban, O. \& Özcan C. C. (2013). Türkiye'de Turizm Gelirleri-Ekonomik Büyüme İlişkisi: Nedensellik

Analizi (1963-2010). Eskişehir Osmangazi Üniversitesi IİBF Dergisi, 8(1), 243-261.

Dereli, D. D. \& Akiş, E. (2019). Türkiye'de Turizm Gelirleri ile İktisadi Büyüme Arasındaki İlişkinin Analizi (1970-2016). İktisadi ve İdari Bilimler Dergisi, 33(2), 467-477.

Dücan, E., Șit, M. \& Șentürk, M. (2016). Ekonomik Büyümeye Bir Katk1 Bağlamında Turizm Gelirleri: Bir Panel Veri Uygulaması. Kahramanmaraş Sütçü İmam Üniversitesi İktisadi ve İdari Bilimler Fakültesi Dergisi, 6(2), 1-14

Ekanayake, E. M. \& Long, A. L. (2011). Tourism Development and Economic Growth in Developing

Countries. Global Conference on Business and Finance Proceedings, 6(2), 520-526.

Erdoğan, S. \& Bozkurt, H. (2008). Türkiye'de Yaşam Beklentisi-Ekonomik Büyüme İlişkisi: ARDL

Modeli ile Bir Analizi. Bilgi Ekonomisi ve Yönetimi Dergisi, 3(1), 25-38.

Esen, E. \& Özata, E. (2017). Turizmin Ekonomik Büyümeye Etkisi: Turizme Dayalı Büyüme Hipotezinin Türkiye İçin Geçerliğinin ARDL Modeli ile Analizi. Anadolu Üniversitesi Sosyal Bilimler Dergisi, 17(1), 43-58.

Gökoval1, U. \& Bahar, O. (2006). Contribution of Tourism to Economic Growth: A Panel Data Approach. Anatolia, 17(2), 155-167.

Göktaş Yılmaz, Ö. (2005). Türkiye Ekonomisinde Büyüme ile İşsizlik Oranları Arasındaki Nedensellik İlişkisi. İstanbul Üniversitesi İktisat Fakültesi Ekonometri ve İstatistik Dergisi, 2, 63-76.

Görüş, M. Ş. \& Türköz, K. (2016). Türkiye'de Petrol Talebinin Fiyat ve Gelir Esneklikleri: ARDL Sınır

Testi ve Nedensellik Analizi. Dokuz Eylül Üniversitesi Sosyal Bilimler Enstitüsü Dergisi, 18(1), 31-54.

Gül, E. \& Yavuz, H. (2011). Türkiye'de Kamu Harcamaları ile Ekonomik Büyüme Arasındaki

Nedensellik İlişkisi: 1963-2008 Dönemi. Maliye Dergisi, 160, 72-85.

Gülbahar, O. (2008). Turizmin Türkiye'de 1980 Sonrası Dönemde Cari İşlemler Dengesine Etkisi. Journal of Qafqaz University, 24, 154-168.

Gülmez, A. (2015). Türkiye'de Dış Finansman Kaynakları Ekonomik Büyüme İlişkisi: ARDL Sınır

Testi Yaklaşımı. Ekonomik ve Sosyal Araştrmalar Dergisi, 11(2), 139-152.

Kanca, O. C. (2015). Turizm Gelirleri ve Ekonomik Büyüme: Türkiye Örneği (1980-2013). Marmara Sosyal Araștormalar Dergisi, 8, 1-14.

Karagöl, E., Erbaykal, E. \& Ertuğrul, H. M. (2007). Türkiye'de Ekonomik Büyüme ile Elektrik Tüketimi İlişkisi: Sınır Testi Yaklaşımı. Doğus Üniversitesi Dergisi, 8(1), 72-80.

Katircioglu, S. T. (2009). Reviting the Tourism-Led Growth Hypothesis for Turkey Using the Bounds

Test and Johansen Approach for Cointegration. Tourism Management, 30, 17-20.

Kızılgöl, Ö. \& Erbaykal, E. (2008). Türkiye'de Turizm Gelirleri ile Ekonomik Büyüme İlişkisi: Bir

Nedensellik Analizi. Süleyman Demirel Üniversitesi İktisadi ve İdari Bilimler Fakültesi Dergisi, 13(2), 351-360.

Kızılkaya, O., Sofuoğlu, E. \& Karaçor, Z. (2016). Türkiye'de Turizm Gelirleri-Ekonomik Büyüme

İlişkisi: ARDL Sınır Testi Yaklaşımı. Yönetim ve Ekonomi, 23(1), 203-214.

Koçak, E. (2014). Türkiye'de Çevresel Kuznets Eğrisi Hipotezinin Geçerliliği: ARDL Sınır Testi Yaklaşımı. İsletme ve İktisat Çalışmalar Dergisi, 2(3), 62-73. 
Koçtepe, E. (2019). Türkiye'de turižm talebinin belirleyicileri: Panel veri analiæi. Yayımlanmamış yüksek lisans tezi, Gazi Üniversitesi Sosyal Bilimler Enstitüsü, Ankara.

Kültür ve Turizm Bakanlığ1 (2020). Turizm İstatistikleri (Ocak-Eylül 2020). https://yigm.ktb.gov.tr.

Lee, C. C. \& Chang, C. P. (2008). Tourism Development and Economic Growth: A Closer Look at Panels. Tourism Management, 29, 180-192.

MacKinnon, J.G. (1996). Numerical Distribution Functions for Unit Root and Cointegration Tests. Journal of Applied Econometrics, 11(6), 601-618.

Pamuk, M. \& Bektaş, H. (2014). Türkiye’de Eğitim Harcamaları ve Ekonomik Büyüme Arasındaki İlişki: ARDL Sınır Testi Yaklaşımı. Siyaset, Ekonomi ve Yönetim Araştırmalar Dergisi, 2(2), 77-90.

Pata, U. K., Yurtkuran, S. \& Kalça, A. (2016). Türkiye'de Enerji Tüketimi ve Ekonomik Büyüme: ARDL Sınır Testi Yaklaşımı. Marmara Üniversitesi İktisadi ve Idari Bilimler Dergisi, 38(2), 255-271.

Pesaran, M. H., Shin, Y. \& Smith, R. J. (2001). Bounds Testing Approaches to the Analysis of Level Relationships. Journal of Applied Econometrics, 16(3), 289- 326.

Polat, E. \& Günay, S. (2012). Türkiye'de Turizm ve İhracat Gelirlerinin Ekonomik Büyüme Üzerindeki Etkisinin Testi: Eşbütünleşme ve Nedensellik Analizi. Süleyman Demirel Üniversitesi Fen Bilimleri Enstitüsü Dergisi, 16(2), 204-211.

Samimi, A. J., Sadeghi, S. \& Sadeghi, S. (2011). Tourism and Economic Growth in Developing Countries:P-VAR Approach. Middle-East Journal of Scientific Research, 10(1), 28-32.

Serin Karacaer, S. (2019). Turizm sektöründe değer zinciri analiz̧: Ürgüp destinasyon örneği. Yayımlanmamış doktora tezi, Gazi Üniversitesi Sosyal Bilimler Enstitüsü, Ankara.

Şahin, D. (2017). Akdeniz Ülkelerinde Turizm ve Ekonomik Büyüme İlişkisinin Analizi. Bingöl Üniversitesi Sosyal Bilimler Enstitüsü Dergisi, 7(14), 115-124.

Tarı, R. (2015). Ekonometri. Kocaeli: Umuttepe Yayınları.

Terzi, H. \& Pata, U. K. (2016). Türkiye’nin İktisadi Büyümesinde Turizm Sektörünün Katkısı. Erciyes Üniversitesi İktisadi ve İdari Bilimler Fakültesi Dergisi, 48, 45-64.

Topallı, N. (2015). Turizm Sektörünün Türkiye'nin Ekonomik büyümesi Üzerindeki Etkisi:1963-2011. Uluslararasi İktisadi ve İdari Incelemeler Dergisi, 7(14), 339-352.

Turan Koyuncu, F. (2015). Turizm Gelirinin Türkiye'nin Makroekonomik Performansına Katkıs1:

Ekonometrik Bir Çözümleme. Uluslararası Sosyal Arastırmalar Dergisi, 8(38), 959-968.

Y1ldız, Z. (2011). Turizmin Sektörünün Gelişimi ve İstihdam Üzerindeki Etkisi. Süleyman Demirel Üniversitesi Vizyoner Dergisi, 3(5), 54-71.

Zengin, B. (2010). Turizm Sektörünün Türkiye Ekonomisine Reel ve Moneter Etkileri. Akademik Incelemeler Dergisi, 5(1), 103-128.

Zortuk, M. \& Bayrak, S. (2013). Seçilmiş Ülkelere Göre Türkiye'nin Turizm Talebi. Ekonometri ve Istatistik, 19, 38-58. 